Eur J Clin Chem Clin Biochem

1995; 33:825-829

(c) 1995 Walter de Gruyter \& Co. Berlin · New York

\title{
Serum Class I and II Alcohol Dehydrogenase Activity During the Course of Viral Hepatitis
}

\author{
By Lech Chrostek and Maciej Szmitkowski
}

Department of Biochemical Diagnostics, Medical School, Białystok, Poland

(Received March 17/July 5, 1995)

Summary: We examined the activities of class I and II alcohol dehydrogenase isoenzymes in the sera of patients with viral hepatitis using the fluorogenic substrates 4-methoxy-1-naphthaldehyde for class I and 6-methoxy-2naphthaldehyde for class II. It was found that serum activities of class I and II alcohol dehydrogenase isoenzymes over the course of five weeks of hospitalisation were higher than those of controls. The greatest increase in activities was found at the onset of disease, exceeding the mean control value by about 30 fold for class I and 4 fold for class II. These activities were lower than that of aminotransferase but higher than those of lactate dehydrogenase, alkaline phosphatase and $\gamma$-glutamyltransferase. Thereafter, the activity of alcohol dehydrogenase isoenzymes gradually decreased, but did not reach the values of the control groups in the last period of the study. Activities of class I and II alcohol dehydrogenase isoenzymes correlated well with those of alanine and aspartate aminotransferases and lactate dehydrogenase in the first weeks of illness. These results clearly demonstrate that especially the activity of class I alcohol dehydrogenase isoenzyme measured by a fluorimetric method can be a useful marker of liver cell damage in the course of viral hepatitis.

\section{Introduction}

Human alcohol dehydrogenase ${ }^{1}$ ) (alcohol : $\mathrm{NAD}^{+}$oxidoreductase, EC 1.1.1.1) exists in multiple molecular forms that have been grouped into four classes (1). Alcohol dehydrogenase classes exhibit important differences in both substrate specificity and tissue distribution. Isoenzymes of class I exist mainly in the liver (up to $95 \%$ of total activity in this organ) (2), and have been termed "classical" alcohol dehydrogenase. Class II in humans is found only in the liver (3), whereas class III is present in all tissues examined (4). The newly discovered gastric alcohol dehydrogenase has been termed class IV (5).

\footnotetext{
1) Enzymes:

Alcohol dehydrogenase (EC 1.1.1.1)

Alanine aminotransferase (EC 2.6.1.2.)

Aspartate aminotransferase (EC 2.6.1.1)

Alkaline phosphatase (EC 3.1.3.2)

$\gamma$-Glutamyltransferase (EC 2.3.2.2)

Lactate dehydrogenase (EC 1.1.1.27)
}

The liver alcohol dehydrogenase isoenzymes have a broad substrate specificity that includes a variety of alcohols and aldehydes of both aliphatic and aromatic character, such as primary and secondary alcohols, diols, and aromatic alcohols $(6,7)$, some hydroxy and keto steroids $(8,9), \omega$-hydroxy fatty acids, retinoids and cytotoxic aldehydes generated in lipid peroxidation (10).

Two fluorogenic substrates for human alcohol dehydrogenase were described by Wierzchowski et al. (11), and classes I and II of this enzyme exhibit different preferences for these substrates. Class I alcohol dehydrogenase can be easily detected by the reduction of 4-methoxy-1-naphthaldehyde to the strongly fluorescent 4methoxy-1-naphthalenemethanol, and class II by the reduction of 6-methoxy-2-naphthaldehyde to 6-methoxy2-naphthalenemethanol. Fluorometric assays of alcohol dehydrogenase isoenzyme activities are more sensitive and specific than the previously used classical method based on NADH absorbance and measurement of the total activity of this enzyme (12). 
This fluorimetric method permits the investigation of alcohol dehydrogenase isoenzyme activity especially in liver cells damaged by cytotoxic or cholestatic agents. In this study, we have investigated the activities of class I and II isoenzymes of alcohol dehydrogenase in the sera of patients with viral hepatitis. These results were also compared with total alcohol dehydrogenase activity and the activities of enzymes which are commonly accepted as liver cell injury markers.

\section{Patients and Methods}

\section{Patients}

Serum of blood from 77 patients (men - 38, women - 39, aged $-17-81$ years) suffering from viral hepatitis B were collected at the onset of disease in the first week of hospitalisation (sample I) and 4 times thereafter at intervals of 7 to 9 days (sample II, III, IV and V). Clinical diagnosis of illness was made on the basis of serological examinations (HBsAg, anti-HBs and Anti-HBc). Serum samples were also obtained from 59 healthy adults aged 20-60 years (men -32 , women -27 ).

\section{Methods}

\section{Fluorimetric assays}

Reaction mixture $(3 \mathrm{ml})$ contained $150 \mu \mathrm{l}$ of $300 \mu \mathrm{mol} / \mathrm{l}$ solution of 4-methoxy-1-naphthaldehyde (substrate for class I) (Aldrich Chemicals Company, Inc. Milwaukee, WI) or 6-methoxy-2-naphthaldehyde (substrate for class II synthesised by Dr. J. Wierzchowski, Department of Physical Chemistry, Medical School, Warsaw, Poland), $100 \mu \mathrm{l}$ of $1 \mathrm{mmol} / \mathrm{l} \mathrm{NADH}$ (Sigma Diagnostics, St. Louis, $\mathrm{MO}$ ), and $2.69 \mathrm{ml}$ of $0.1 \mathrm{~mol} / 1$ sodium phosphate buffer, $\mathrm{pH} 7.6$. After equilibration for $5 \mathrm{~min}$, the reaction was initiated by the addition of $60 \mu \mathrm{l}$ of serum. The changes in fluorescence were recorded for up to $10 \mathrm{~min}$ on an Aminco Bowman spectrofluorimeter (excitation wavelength $316 \mathrm{~nm}$, emission wavelength $370 \mathrm{~nm}$ for class I and $360 \mathrm{~nm}$ for class II). Subsequently, $60 \mu \mathrm{l}$ of $200 \mu \mathrm{mol} / \mathrm{l} 4$ methoxy-1-naphthalenemethanol (for measurement of class I) or 6-methoxy-2-naphthalenemethanol (for measurement of class II), synthesised by $\mathrm{Dr}$. J. Wierzchowski was added to provide an internal standard and its fluorescence intensity was then measured. For the evaluation of alcohol dehydrogenase activity, two assays were carried out: one with substrate alone and the second with substrate and $50 \mu \mathrm{l}$ of a $12 \mathrm{mmol} / \mathrm{l}$ solution of 4-methylpyrazole as a specific inhibitor of alcohol dehydrogenase activity (Aldrich Chemicals Company, Inc. Milwaukee, WI). The rate of reaction (initial velocities) was calculated as $\mathrm{mU} / \mathrm{l}$ (11).

\section{Spectrophotometric assays}

Serum total alcohol dehydrogenase activity was estimated at $\mathrm{pH}$ 9.2 (13) according to the method of Bonnichsen \& Brink (14) using the Technicon RA-1000 analyzer. The enzyme was assayed at 340 $\mathrm{nm}$ and $37^{\circ} \mathrm{C}$ for 3 minutes in the reaction mixture $(362 \mu \mathrm{l})$ which contained $18 \mu \mathrm{l}$ of serum and $344 \mu \mathrm{l}$ of $0.1 \mathrm{~mol} / \mathrm{l}$ glycine buffer. In this volume the final NAD (Sigma Diagnostics, St. Louis, MO) and ethanol (Aldrich Chemicals Company, Inc. Milwaukee, WI) concentrations were $0.44 \mathrm{mmol} / \mathrm{l}$ and $28 \mathrm{mmol} / \mathrm{l}$, respectively. The control tubes contained the reaction mixture without alcohol. Using the specific inhibitor of alcohol dehydrogenase 4-methylpyrazole (Sigma Diagnostics, St. Louis, MO) at a final concentration of 12 $\mathrm{mmol} / \mathrm{l}$, non-specific activity was subtracted.

\section{Determination of other enzymes}

The activity of alanine and aspartate aminotransferases, lactate dehydrogenase, $\gamma$-glutamyltransferase and alkaline phosphatase were measured in an Express Plus biochemical analyzer using diagnostic kits from bioMerieux.

\section{Statistical analysis}

Statistical analysis was performed using the Wilcoxon's test for paired samples and Pearson's correlation coefficient. The mean value and standard deviation (SD) of results were calculated for all tested groups and samples.

\section{Results}

As presented in figure 1, we found that the serum activity of class I alcohol dehydrogenase isoenzymes was elevated in each period of the course of viral hepatitis, and was highest at the onset of disease (sample I, 14.59 $\pm 15.88 \mathrm{mU} / \mathrm{l}$ ), exceeding by 30 fold the mean value of the control group. After some time, this isoenzyme activity gradually decreased and in the following samples reached the following values: $10.11 \pm 10.33 \mathrm{mU} / \mathrm{l}, 4.79$ $\pm 5.35 \mathrm{mU} / \mathrm{l}, 4.42 \pm 4.52 \mathrm{mU} / 1$ and $4.78 \pm 3.69 \mathrm{mU} / 1$. However, in the last period of examination, the activities of class I alcohol dehydrogenase isoenzymes did not return to the values of the control group. The multiples of the mean control value were about 19, 9, 8 and 9 for samples II, III, IV and V, respectively. These were higher than the multiple of lactate dehydrogenase ${ }^{1}$ ) (mean 1.13), alkaline phosphatase $\left.{ }^{1}\right)(2.55)$ and $\gamma$-glutamyltransferase $^{1}$ ) (8.29) but significantly lower than aspartate $\left.^{1}\right)$ (20.7) and alanine aminotransferases ${ }^{1}$ ) (16.76) (tab. 1). During the whole observation period we observed statistically significant differences in activities of class I alcohol dehydrogenase isoenzymes between the patients and the control group.

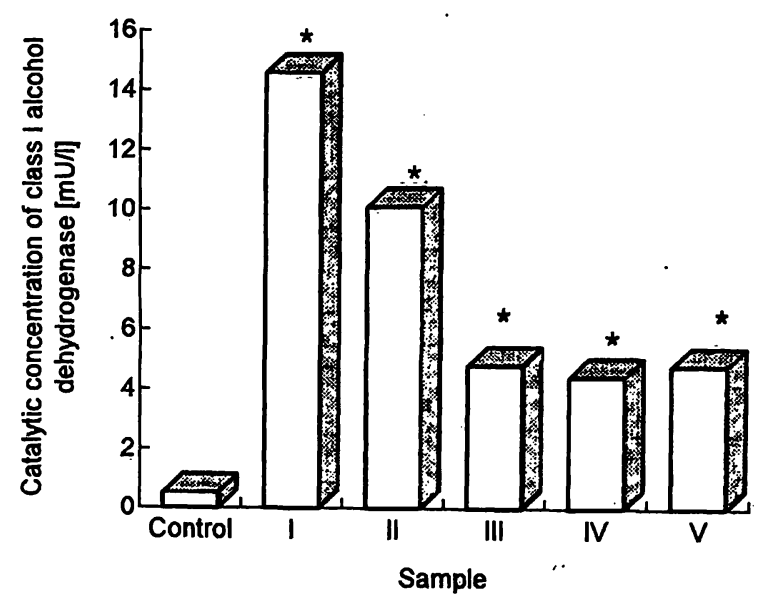

Fig. 1 Catalytic concentration of class I alcohol dehydrogenase in the sera of patients with viral hepatitis. $\mathrm{I}-\mathrm{V}=$ samples in the course of viral hepatitis ${ }^{*} \mathrm{p}<0.001$, compared with control 
Tab. 1 The activity of liver injury enzymatic markers in the course of viral hepatitis.

\begin{tabular}{lllllr}
\hline Group & $\begin{array}{l}\text { Alanine } \\
\text { aminotransferase } \\
\text { U/I }\end{array}$ & $\begin{array}{l}\text { Aspartate } \\
\text { aminotransferase } \\
\text { U/l }\end{array}$ & $\begin{array}{l}\text { Lactate } \\
\text { dehydrogenase } \\
\text { U/l }\end{array}$ & $\begin{array}{l}\gamma \text {-Glutamyl- } \\
\text { transferase } \\
\text { U/l }\end{array}$ & $\begin{array}{l}\text { Alkaline } \\
\text { phosphatase } \\
\text { U/l }\end{array}$ \\
\hline Control & $18 \pm 7$ & $16 \pm 5$ & $172 \pm 31$ & $17 \pm 9$ & $23 \pm 7$ \\
Sample I & $627 \pm 407$ & $725 \pm 522$ & $254 \pm 118$ & $145 \pm 118$ & $58 \pm 24$ \\
Sample II & $390 \pm 347$ & $445 \pm 464$ & $209 \pm 102$ & $131 \pm 107$ & $55 \pm 27$ \\
Sample III & $239 \pm 226$ & $234 \pm 257$ & $193 \pm 85$ & $133 \pm 131$ & $51 \pm 28$ \\
Sample IV & $144 \pm 146$ & $158 \pm 168$ & $183 \pm 87$ & $139 \pm 103$ & $52 \pm 25$ \\
Sample V & $110 \pm 131$ & $97 \pm 114$ & $138 \pm 43$ & $157 \pm 153$ & $78 \pm 63$ \\
\hline
\end{tabular}

Tab. 2 Correlation coefficient between activity of alcohol dehydrogenase isoenzymes and of other enzymes.

\begin{tabular}{|c|c|c|c|c|c|c|c|c|c|c|c|c|c|}
\hline \multicolumn{2}{|c|}{$\begin{array}{l}\text { Alcohol } \\
\text { dehydrogenase }\end{array}$} & \multicolumn{2}{|c|}{$\begin{array}{l}\text { Alanine } \\
\text { aminotrans- } \\
\text { ferase }\end{array}$} & \multicolumn{2}{|c|}{$\begin{array}{l}\text { Aspartate } \\
\text { aminotrans- } \\
\text { ferase }\end{array}$} & \multicolumn{2}{|c|}{$\begin{array}{l}\text { Lactate } \\
\text { dehydrogenase }\end{array}$} & \multicolumn{2}{|c|}{$\begin{array}{l}\gamma \text {-Glutamyl- } \\
\text { transferase }\end{array}$} & \multicolumn{2}{|c|}{$\begin{array}{l}\text { Alkaline } \\
\text { phosphatase }\end{array}$} & \multicolumn{2}{|c|}{$\begin{array}{l}\text { Total alcohol } \\
\text { dehydro- } \\
\text { genase }\end{array}$} \\
\hline Isoenzymes & week & $r$ & $\alpha$ & $r$ & $\alpha$ & $r$ & $\alpha$ & $r$ & $\alpha$ & $r$ & $\alpha$ & $\mathbf{r}$ & $\alpha$ \\
\hline \multirow[t]{5}{*}{ Class I } & I & 0.40 & $0.00 *$ & 0.37 & $0.00 *$ & 0.31 & $0.00 *$ & -0.08 & 0.46 & 0.02 & 0.86 & -0.09 & 0.42 \\
\hline & II & 0.41 & $0.00 *$ & 0.26 & $0.03 *$ & 0.07 & 0.55 & -0.03 & 0.82 & 0.14 & 0.23 & -0.12 & 0.30 \\
\hline & III & 0.34 & $0.01 *$ & 0.38 & $0.00 *$ & 0.16 & 0.24 & -0.08 & 0.57 & 0.30 & 0.29 & -0.00 & 0.97 \\
\hline & IV & 0.18 & 0.33 & 0.20 & 0.27 & -0.28 & 0.13 & 0.18 & 0.34 & -0.00 & 0.96 & -0.08 & 0.67 \\
\hline & V & 0.01 & 0.96 & 0.04 & 0.89 & -0.04 & 0.89 & -0.01 & 0.97 & -0.14 & 0.63 & 0.12 & 0.70 \\
\hline \multirow[t]{5}{*}{ Class II } & I & 0.42 & $0.00 *$ & 0.52 & $0.00^{*}$ & 0.59 & $0.00 *$ & -0.03 & 0.79 & -0.06 & 0.59 & 0.33 & $0.00^{*}$ \\
\hline & II & 0.35 & $0.00 *$ & 0.33 & $0.00^{*}$ & 0.30 & $0.01 *$ & -0.03 & 0.83 & 0.14 & 0.23 & -0.00 & 0.99 \\
\hline & III & 0.03 & 0.81 & 0.19 & 0.17 & 0.12 & 0.39 & -0.12 & 0.38 & 0.04 & 0.77 & -0.11 & 0.45 \\
\hline & IV & 0.25 & 0.17 & 0.13 & 0.49 & -0.21 & 0.27 & -0.22 & 0.24 & -0.17 & 0.37 & -0.36 & 0.05 \\
\hline & $\mathrm{V}$ & 0.64 & $0.02 *$ & 0.54 & 0.05 & 0.20 & 0.50 & -0.43 & 0.14 & -0.14 & 0.65 & 0.24 & 0.43 \\
\hline
\end{tabular}

* linear dependence

The activities of class I alcohol dehydrogenase isoenzymes correlated with those of alanine and aspartate aminotransferases in the first period of the disease (sample I, II and III), but did not correlate with markers of cholestasis such as $\gamma$-glutamyltransferase and alkaline phosphatase (tab. 2).

The activities of class II alcohol dehydrogenase isoenzymes were also significantly increased during the course of viral hepatitis (fig. 2). The highest level was observed at the beginning of the study (sample I) and was evaluated at $46.85 \pm 36.73 \mathrm{mU} / \mathrm{l}$, about 4 times above the mean control value. In the second period (sample II), activity of class II isoenzymes decreased to $38.73 \pm 29.29 \mathrm{mU} / 1$ and was almost at the same level in sample IV (34.16 $\pm 29.39 \mathrm{mU} / \mathrm{l})$. The multiples of mean control value in these three samples were about 2-3 times. At the end of the investigation (sample V), the activity of class II alcohol dehydrogenase isoenzymes slightly decreased, reaching a mean value of $22.05 \pm 16.85 \mathrm{mU} / 1$, which was only $83 \%$ higher than the control value.

In comparison to other enzyme activities, it was found that the multiples of class II alcohol dehydrogenase iso- enzyme activity were similar to those of alkaline phosphatase (2.5 times), lower than the multiple of $\gamma$-glutamyltransferase and aminotransferases but higher than those of lactate dehydrogenase (1.5 times) (tab. 1).

The correlation study (tab. 2) showed a good correlation coefficient between the activities of class II alcohol de-

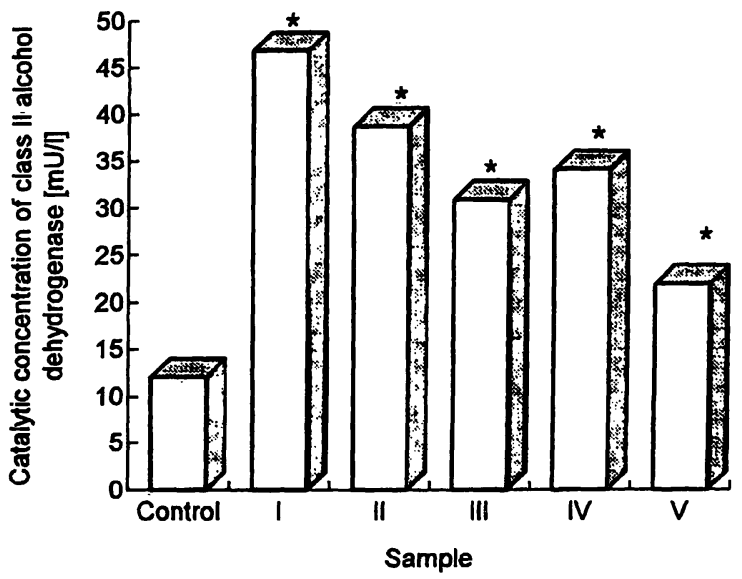

Fig. 2 Catalytic concentration of class II alcohol dehydrogenase in the sera of patients with viral hepatitis.

$\mathrm{I}-\mathrm{V}=$ samples in the course of viral hepatitis

${ }^{*} \mathrm{p}<0.05$, compared with control 
hydrogenase isoenzymes and alanine aminotransferase, aspartate aminotransferase and lactate dehydrogenase in the first two samples, and in the last period of the study.

The total alcohol dehydrogenase activity measured at $\mathrm{pH}$ 9.2 was higher than that of the controls (fig. 3). The greatest increase of activity was noted in the second sample ( $60 \%$ in comparison to mean control value), and subsequently the activity gradually decreased but did not reach the level of the control group. Total alcohol dehydrogenase activity measured by a spectrophotometric method correlated only with the activity of class II isoenzymes in the first week of hospitalisation.

\section{Discussion}

Viral hepatitis accompanied by cellular injury and necrosis leads to the release of cytoplasmic enzymes such as aminotransferases. The activities of these enzymes correlate well with the severity of the condition and their regular monitoring is a fundamental diagnostic marker of liver cell damage during this disease (15).

In our study we report that the serum alcohol dehydrogenase isoenzyme activity during viral hepatitis was similar to the activity of classical aminotransferases. Thus, the greatest increase of both alcohol dehydrogenase isoenzymes and aminotransferases activities was found at the onset of disease. Aminotransferase activities were greatly elevated and exceeded the mean value of the control group by about 40 fold. The next position was reserved for isoenzymes of class I of alcohol dehydrogenase activity, the mean value at the onset of disease was more than 30 times higher than the control value. Thereafter, we found the multiples of $\gamma$-glutamyltransferase activity (8.5), class II alcohol dehydrogenase

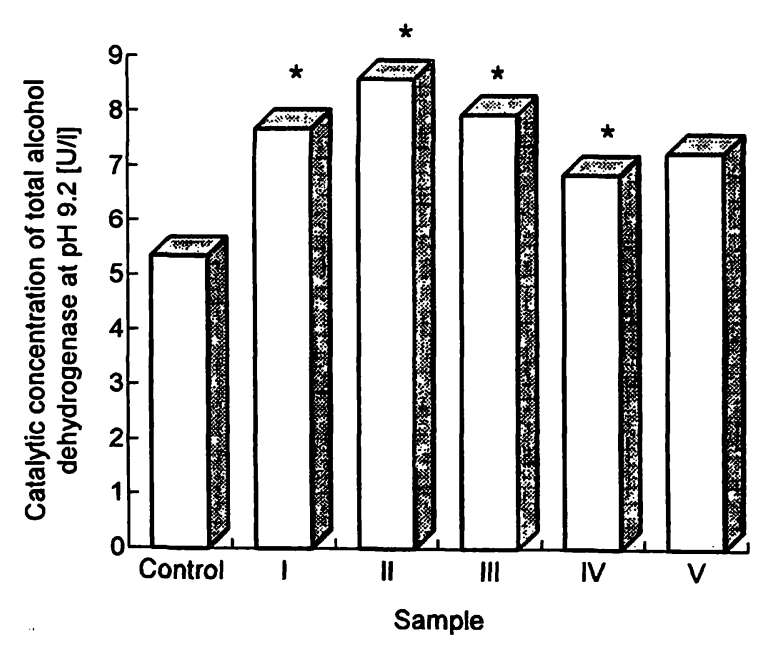

Fig. 3 Catalytic concentration of total alcohol dehydrogenase measured by spectrophotometric method in the sera of patients with viral hepatitis.

$\mathrm{I}-\mathrm{V}=$ samples in the course of viral hepatitis

$* \mathrm{p}<0.05$, compared with control
(3.9), alkaline phosphatase (2.5), total alcohol dehydrogenase activity (1.4) and lactate dehydrogenase (1.5).

Schmidt et al. showed that $\beta$-glutamyltransferase appears to be an extremely sensitive marker (sensitivity 95\%) of liver dysfunction (16). According to these authors, other enzymes are less sensitive but are often more specific for a particular hepatic syndrome. It is known that class I and especially class II alcohol dehydrogenase isoenzymes are the most specific of all tested enzmyes because serum activity of class II isoenzyme is derived only from liver cells (3), and hepatic class I isoenzymes represent $80-95 \%$ of total activity of this class in humans (2).

This study showed that the activity of class I alcohol dehydrogenase isoenzymes in viral hepatitis increased in parallel with the development of the disease, as was the case for aminotransferases but not $\gamma$-glutamyltransferase, which was slightly altered during the illness. In the course of the disease the activity of class I alcohol dehydrogenase isoenzymes quickly decreased as did aminotransferase activities. In contrast the activity of class II alcohol dehydrogenase isoenzymes slowly decreased as did that of other enzymes, especially $\gamma=$ glutamyltransferase and alkaline phosphatase, although this was not confirmed in the correlation study. These lower multiples of increase for class II alcohol dehydrogenase than class I may be explained by the fact that this class is present as $\pi \pi$ homodimers while class I isoenzymes are heterodimers consisting of $\alpha, \beta$ and $\gamma$ subunits.

Mezey et al. reported that elevation of serum alcohol dehydrogenase activity occurred in acute parenchymal liver cell damage caused by viruses (17), and the level of enzyme activity early in the course of hepatitis generally paralleled that of serum aspartate aminotransferase. In our study we noted linear dependence of both classes of alcohol dehydrogenase with alanine and aspartate aminotransferases in the early phase of the disesae. This linearity disappeared after two or three weeks for class I and II, respectively, and was noted once again between class I alcohol dehydrogenase and alanine aminotransferase after five weeks of hospitalisation.

Because aminotransferases are present in all tissues, Mezey et al. (17) suggested that alcohol dehydrogenase is similar to enzymes such as ornithine carbamyl transferase and sorbitol dehydrogenase, which are liver specific and their elevated serum levels differentiate acute liver injury from acute damage to other organs.

From the data presented in the tables, it is clear that alcohol dehydrogenase activity detected by a spectrophotometric method generally did not correlate with the activity of class I and II isoenymes, which in turn correlated with the activity of aminotransferases but not with 
that of $y$-glutamyltransferase. These results indicate that the activities of $\gamma$-glutamyltransferase and aminotransferases did not correlate in this study. This was confirmed by us (in unreported data).

In conclusion, the activity of class I and II alcohol dehydrogenase isoenzymes measured by a fluorimetric method with a high specific substrate is a specific biochemical marker of liver cell injury during viral hepatitis, comparable to the activities of alanine and asparatate aminotransferases and much better than those of en- zymes such as $\gamma$-glutamyltransferase, alkaline phosphatase and lactate dehydrogenase. Class II alcohol dehydrogenase isoenzymes, although only hepatic, yielded a much lower multiple of increase in comparison with class I but was similar to other tested enzymes with the exception of aminotransferases.

\section{Acknowledgements}

The authors thank Dr. J. Wierzchowski for the preparation of the purified substrate and products.

\section{References}

1. Strydom DS, Vallee BL. Characterization of human alcohol dehydrogenase isoenzymes by high-performance liquid chromatographic peptide mapping. Anal Biochem 1982; 123:422-9.

2. Boleda MD, Julia P, Moreno A, Pares X. Role of extrahepatic alcohol dehydrogenase in rat ethanol metabolism. Arch Biochem Biophys 1989; 274:74-81.

3. Bosron WF, Li T-K, Dafeldecker WP, Vallee BL. Human $\pi$ alcohol dehydrogenase: kinetic and molecular properties. Biochemistry $1979 ; 18: 1101-5$.

4. Adinolfi A, Adinolfi M, Hopkinson DA. Immunological and biochemical characterization of human alcohol dehydrogenase $\chi$-ADH isozymes. Ann Hum Genet 1984; 48:1-10.

5. Yin S-J, Wang M-F, Liao C-S, Wu C-W. Identification of a human stomach alcohol dehydrogenase with distinctive kinetics properties. Biochem Int 1990; 22:829-35.

6. Pietruszko R, Crawford K, Lester D. Comparison of substrate specificity of alcohol dehydrogenase from human liver, horse liver and yeast towards saturated and 2-enoic alcohols and aldehydes. Arch Biochem Biophys 1973; 59:50-60.

7. Pietruszko R. Nonethanol substrates of alcohol dehydrogenase. In: Majchrowitcz E, Noble EP, editors. Biochemistry and pharmacology of ethanol. New York: Plenum Press, 1976; 1:87106.

8. Waller G, Theorell H, Sjovall J. Studies on the stereospecificity of liver alcohol dehydrogenase as a $3 \beta$-hydroxy- $5 \beta$-cholanic acid dehydrogenase. Arch Biochem Biophys 1965; 111:671-84.

9. Reynier M, Theorell H, Sjovall J. Studies on the stereospecificity of liver alcohol dehydrogenase (LADH) for 3 $\beta$-hydroxy$5 \beta$-steroids. Inhibition effects of pyrazole and of a $3 \alpha$-hydroxycholanic acid. Acta Chem Scand 1969; 23:1130-5.

10. Boleda MD, Saubi N, Farres J, Pares X. Physiological substrates for rat alcohol dehydrogenase classes: aldehydes of

lipid peroxidation, $\omega$-hydroxyfatty acids, and retinoids. Arch Biochem Biophys 1993; 307:85-90.

11. Wierzchowski J, Dafeldecker WP, Holmquist B, Vallee BL. Fluorometric assays for isozymes of human alcohol dehydrogenase. Anal Biochem 1990; 178:57-62.

12. Elghaffar AA, Chrostek L, Szmitkowski M. Measurement of serum alcohol dehydrogenase activity at different $\mathrm{pH}$-values during the course of viral hepatitis in children. J Clin Chem Clin Biochem 1990; 28:497-9.

13. Szmitkowski M, Chrostek L. Alcohol dehydrogenase (ADH) activity at different $\mathrm{pH}$ in the sera of alcoholics. In: Galteau M$\mathrm{M}$, editor. Biologie prospective. Paris: John Libbey Eurotext, 1989:659-62.

14. Bonnichsen RK, Brink NO. Liver alcohol dehydrogenase. In: Colowick SP, Nathan NO, editors. Methods in enzymology. New York: Academic Press, 1; 1955:495-500.

15. Zelman S, Wang CC, Appelhanz I. Transaminases in serum and liver correlated with liver necrosis in needle aspiration biopsies. Am J Med Sci 1959; 237:323-34.

16. Schmidt E, Schmidt FW. Enzyme diagnosis in disease of the liver and biliary system. In: Schmidt EW, Trautschold I, Friedel R, editors. Advances in clinical enzymology. Basel: Karger, 1979:239-92.

17. Mezey E, Cherrick GR. Serum alcohol dehydrogenase: an indicator of intrahepatic cholestasis. N Engl J Med 1968; 279:241-8.

M. Szmitkowski M. D., Ph.D.

Department of Biochemical Diagnostics

Institute of Laboratory Diagnostics

Medical School

M. Skłodowska-Curie 24A

PL-15-276 Białystok

Poland 
